TRAMES, 2009, 13(63/58), 1, 64-82

\title{
HOLLYWOOD, DEMILLE AND HOMAGE: FIVE HEURISTIC CATEGORIES
}

\author{
Anton Karl Kozlovic \\ Flinders University, Adelaide, Australia
}

\begin{abstract}
Producer-director Cecil B. DeMille was a cofounder of Hollywood and a progenitor of Paramount studio who became a movie legend and master of the American biblical epic via deft aesthetic skillfulness. Although frequently dismissed, denied or derided by critics throughout his career, he was so successful in profit-obsessed Hollywood that rivals attempted to emulate his box-office receipts by appropriating him, but they usually failed. Deploying humanist film criticism as the guiding analytical lens, the critical literature was selectively scanned and five subtle categories of industry homage to DeMille were identified, namely: (a) the film clip as homage, (b) the man as homage, (c) imitation as homage, (d) association as homage, and (e) remodeling as homage. Each interdisciplinary heuristic category was briefly explicated and illustrated employing copious inter-genre exemplars to demonstrate their diversity. Further researches into DeMille studies, homage typologies and their histories are warranted, recommended and are already long overdue.
\end{abstract}

DOI: $10.3176 / \operatorname{tr} .2009 .1 .04$

Keywords: Cecil B. DeMille, Hollywood, Paramount studio, homage, film terminology, religion, biblical epics

\section{Introduction}

Cecil B. DeMille ${ }^{1}$ (1881-1959), affectionately known as C.B., was a cofounder of Hollywood and a progenitor of Paramount studio who helped turn an obscure Californian orange grove into an international movie production center that became the synonym for filmmaking worldwide (Birchard 2004, Cherchi Usai and

1 Many scholars have spelled Cecil's surname as 'De Mille' or 'de Mille' or 'deMille' (which he employed for personal private use), however, for professional public use, he spelt his name as 'DeMille' (DeMille and Hayne 1960:6), and so it will be employed herein unless quoting, along with 'Cecil' and 'C.B.' as appropriate. 
Codelli 1991, DeMille and Hayne 1960, Edwards 1988, Essoe and Lee 1970, Higashi 1985, 1994, Higham 1973, Koury 1959, Louvish 2008, Noerdlinger 1956, Orrison 1999, Ringgold and Bodeen 1969). Not only did DeMille help institute "the Age of Hollywood" (Paglia 1994:12), but this pioneering "auteur of auteurs" (Vidal 1995:303) became the "King of Hollywood" (Louvish 2008:438) and the master of the American biblical epic who was subsequently tagged "King of the epic Biblical spectacular" (Finler 1985:32), the "high priest of the religious genre" (Holloway 1977:26) and the "arch apostle of spectacle" (Clapham 1974:21).

DeMille-the-director ${ }^{2}$ deserved these accolades with his indelible Christian, religious and biblical spectaculars: Joan the Woman, The Ten Commandments (1923), The King of Kings, The Sign of the Cross, The Crusades, Samson and Delilah and The Ten Commandments (1956). But DeMille was far more than a great epic filmmaker who excelled doing cinematic renditions of the Old Testament (OT), the New Testament (NT) and ancient Judeo-Christian adventures with his deft page-to-projector renditions of Holy Writ and sacred history. As Barry Norman (1985:160) assessed his career, DeMille "was a giant in an industry that spawns a multitude of self-inflated pygmies... and in his career as a director he destroyed the Temple at Gaza, burnt Rome and parted the Red Sea, not once but twice. Even God can't beat that."

DeMille's film career was so long (1913-1959) and financially successful that he became an American cultural icon, particularly remembered as the archetypical image of a film director charging around the set in puttee pants shouting instructions through a megaphone as sycophants attended to his every whim. The seventy feature films that he personally directed ( 52 silent, 18 sound), the films that he produced but did not direct, and the unaccredited creative input he provided friends, relatives and his own fledgling production company is itself sufficient reason to justify his Hollywood icon status (Birchard 2004). However, his cultural referent reputation was further cemented by numerous industry rivals who repeatedly tried to capitalize upon DeMille's fame, status and notoriety throughout his career, and into modern times as recently evidenced by the 2000 madcap comedy, Cecil B. DeMented. Indeed, as Lee Pfeiffer (2006:6) argued: "it would be inconceivable to write about influential movies and not pay homage to DeMille." The writer agrees with this claim and furthermore argues that C.B. was widely referenced many times by his peers via direct and indirect, positive and negative allusions to himself and his films within their rival productions; albeit, frequently under-valued by academia.

Given DeMille's popular success, professional longevity and Hollywood superstar status as a cinematic lay preacher, it is not too surprising to find that his biblical epics in particular were appropriated by other film directors as a de facto

2 There is not one DeMille but many DeMilles. His career was so complex and multi-faceted that to describe, let alone justify each aspect would be prohibitive, in fact: "It is impossible to describe the career of Cecil B. DeMille in a few words. A whole book is needed" (Kardish 1972:133). Therefore, concise hyphenated compound terms will be used throughout to help disentangle his various roles and avoid needless explanation or boring repetition. 
form of flattery and/or noted by critics for their sociocultural profundity, particularly his 1956 Technicolor testament, The Ten Commandments. Although "homage" is typically defined as a "complimentary allusion in a film to another film or filmmaker" (Konigsberg 1989:159), there are many other varieties of homage available that can encompass neutral, non-complimentary or even derogatory cultural references. Somewhat surprisingly, to date there are no review articles, monographs or books specifically devoted to the broader arena of homage studies, whether its Hollywood history, forms and functions, let alone its relationship to DeMille documented in one convenient place before, therefore, just beginning this important work would be a significant service to both film scholarship and DeMille studies.

Consequently, utilizing basic humanist film criticism as the guiding analytical lens (i.e. examining the textual world inside the frame, but not the world outside the frame-see Bywater and Sobchack 1989:chpt. 2), the critical film and DeMille literature was selectively reviewed and integrated into the text to enhance narrative coherence (albeit, with a strong reportage flavor). With a simple thematic emphasis upon compiling pertinent illustrative examples of the phenomenon, five interdisciplinary heuristic categories of this industry appropriation habit were identified and subtly delineated herein (with some minor overlap). Namely: (a) the film clip as homage: intertextuality and DeMille, (b) the man as homage: DeMille as subject, object and personal parallelism, (c) imitation as homage: copying DeMille as honoring, flattery and status theft, (d) association as homage: capitalizing upon DeMille's currency, name and reputation, and (e) remodeling as homage: the spin-offs, remakes and rivals of DeMille's films. The following is a brief introductory explication of each of these DeMille-related homage categories employing copious inter-genre exemplars to demonstrate the range and diversity of this under-studied film studies phenomenon.

\section{The film clip as homage: intertextuality and DeMille}

As Graham Allen (2000:175) argued: "Films... just like literary texts, constantly talk to each other as well as talking to the other arts," therefore the cinematic appropriation of DeMille is not only a form of flattery, it is also the cinematic equivalent of selecting a textbook quote to illustrate a point in your work. A good DeMillean cinematic example of this usage occurred in the classic UFO film, Close Encounters of the Third Kind when the parting of the Red Sea scene from the 1956 The Ten Commandments was shown on TV in the protagonist's home (and somewhat ironic since the original widescreen epic was designed to rival the arrival of television). Many commentators noted this intertextual connection (e.g., Baxter 1996:149, 252, McConnell 1979:49). Steven Spielberg supposedly deployed it to juxtapose the cosmos with suburban reality (Crawley 1983:57), while Neil Sinyard (1986) suggested that: 
The Ten Commandments (1956) is showing on television (because of its length, Neary [Richard Dreyfuss] is planning only to let his children see five), and Spielberg's film not only matches it for technique - the landing of the Mother Ship being the cinema's most spectacular special effect since de Mille's parting of the Red Sea - it surpasses it in its religious sense of awe” $(47,50)$.

Indeed, Neary's "five" commandments comment was itself another subtle DeMillean homage, but this time to the 1923 version of The Ten Commandments when DeMille's bosses ordered that he cut back his spending, so he snapped: "stop now and release it as The Five Commandments?" (Lasky and Weldon 1957:168) and then stomped out the room. This incident became another memorable moment in Hollywood folklore.

According to Babington and Evans (1993:3), the 1956 Red Sea scene was located "in the context of the extra-terrestrial mysteries unfolding, Richard Dreyfus's and Teri Garr's children insist on watching a television replay just at the moment of the opening of the Red Sea... Spielberg's homage is a salutary reminder that these films were memorable cinema experiences for many viewers." Not only were they memorable cinematic experiences, but Frank McConnell (1979:49) suggested that the Red Sea sequence was shown "precisely to illustrate the true capability of filmmaking for transcendence," while Douglas Brode (1995) suggested that it was done in an attempt to inject religious experience back into one's mundane secular life. As he explained:

"Its four and a half hours long," Ronnie [Teri Garr] complains about Cecil B. DeMille's 1956 version of The Ten Commandments. Spielberg was too subtle to cut to a close-up of Charlton Heston, waving his staff in the wind, rather allowing the identity of the televised film to be buried in his own film's texture. Still, one key element developed in Close Encounters of the Third Kind is religion, particularly in relationship to the soulless existence so many contemporary people lead. The Neary family is obviously a descent, hardworking, semifunctional American family, yet there is no vestige of any religious affiliation in their home, no suggestion they belong to a church and attend, if only on Sundays. Watching a religious film, then, is the nearest contact these kids will come to the Bible; indeed, televised DeMille is essentially the Bible for the TV generation. Significantly, Ronnie insists the kids don't need what is to be found here, even stating, "There's nothing in it for them." On the other hand, Roy [Richard Dreyfuss] argues "it would be good for them." However, unconsciously, he is speaking for himself: What Roy wants, indeed, needs, is some sort of center to his existence, which can only come from a spirituality missing in his daily routine (68).

DeMille's OT epic was not only acknowledged for this inherent religiosity, but it was also appropriated for its cultural, sexual and comedic connotations. For example, in the cop comedy, The Naked Gun 2 1/2: The Smell of Fear, Lieutenant Frank Drebin (Leslie Nielsen) was having sex off-screen with his lover when their romantic moment was intercut with a clip showing the erection of Pharaoh Sethi's jubilee obelisk from the 1956 The Ten Commandments to make this Freudian phallic point stick out (or up). The same The Ten Commandments was also 
visually referenced within Jocelyn Saab's Kanya Ya Ma Kan, Beyrouth as part of an elderly cinephile's collection of Beirut archival footage, Arab cinema and worthy Western film clips. In To Wong Foo, Thanks for Everything! Julie Newmar, a film clip showing a lovelorn Nefretiri (Anne Baxter) from The Ten Commandments was being used by delightful drag queens as a style role model for a lovelorn Snydersville girl (Hammond 1996), thus demonstrating that DeMille's 1950s notion of sexuality is still relevant in the modern (Hicksville) world, if not exactly to mainstream womanhood!

Similar intertextual connections were made regarding DeMille's 1923 The Ten Commandments. For example, in Widows' Peak, homage to C.B. is made when Miss Catherine O'Hare (Mia Farrow) desired all her personal enemies dead so she goes to the movies and watches Pharaoh's forces being wiped out to externalize and partially satiate her deadly desire. Ben Burtt's (1996) documentary, Special Effects: Anything Can Happen also contained scenes from the silent The Ten Commandments, but understandably so considering that DeMille's first parting of the Red Sea was a spectacular SFX milestone that still thrills today. Even DeMille's 1934 Egyptian biopic, Cleopatra was helped "by a liberal use of stock footage from his own 1923 production of The Ten Commandments" (Hopkins 1980:361), while Joe Franklin (1976) reported that a fan once asked him:

Q. Was DeMille's [The] Ten Commandments ever remade in the early 30's? I could have sworn I saw it then, but now I can find no reviews or other records of it.

A. No, there was no remake-until the current one of course [The Ten Commandments (1956)]. But in the early days of sound Paramount brought out a feature called Modern Commandments [1927] which used the big battle scenes and other highlights from the silent DeMille film. Maybe this is what you're thinking of (247).

Furthermore, according to Roy Armes (1975:227), Kenneth Anger had cut "a wild homosexual orgy scene with stagey scenes of Christ entering Jerusalem taken from the old De Mille epic [The] King of Kings" and placed it into his cult film about gay, Nazi bikers, Scorpio Rising. However, Anger recently claimed that it was actually "a Lutheran Sunday School film, called The Last Journey to Jerusalem" (Anger 2006:6), not DeMille's classic Jesus film. Nevertheless, for Armes to even think that the Jesus clip was from DeMille was itself a telling psychological example of a homage in the form of a "misidentification mistake," and a very strong indication of DeMille's marketing-cum-cultural penetration into the public consciousness; as also indicated when Larry J. Kreitzer (2003:289) mistook the 1925 Ben-Hur: A Tale of the Christ as a DeMille production rather than a Fred Niblo film.

In addition to using intertextual film clips, DeMille was himself cinematically honored in other genres by the greats and not-so-greats of Hollywood cinema. 


\section{The man as homage: DeMille as subject, object and personal parallelism}

In the classic reflexive film about Hollywood, Sunset Blvd., which was "Billy Wilder's poisoned love letter to the silent cinema" (Koszarski 1994:211), the butler-chauffeur, Max von Mayerling (Erich von Stroheim) revealed to the downand-out screenwriter-turned-gigolo, Joe Gillis (William Holden) that he was originally Norma Desmond's (Gloria Swanson's) director. Not only did he discover her at sixteen and made her into a screen star, but he was her first husband who now lovingly looks after Norma as her literal servant. Max proudly claimed that in those glorious days there were only three great film directors, namely, D.W. Griffith, Cecil B. DeMille and (the fictional) Max von Mayerling (himself). Not only was DeMille repeatedly referred too throughout the screen dialogue, but he also got a starring role playing himself as a biblical film director while actually shooting his ancient OT epic, Samson and Delilah on the real Paramount Stage 18 (Perry 1993:70). As the Variety reviewer claimed: "The other performer rating more than a mention is Cecil B. DeMille. He plays himself with complete assurance in one of the few sympathetic roles" (Elley 1994:880).

The parallel between DeMille's and Swanson's real lives were also disturbingly accurate, and worthy of further research elsewhere. However, the most iconic moment occurred at film's end when the delusional Norma dramatically descended a staircase thinking that she is Salome performing for Mr. DeMille. Max is behind the camera and allowed her to enjoy these last moments of illusionary grandeur by pretending to be DeMille, who is then immortalized by Norma's closing instruction: "All right, Mr. DeMille, I'm ready for my close-up." Wilder also fused compassion with success and enjoyment for the fictional Max von Mayerling and the real Erich von Stroheim, both of whom had directorial careers in silent cinema that died when Hollywood entered the sound era (Noble 1950). DeMille himself helped lead that charge with Dynamite and proved himself once again to be "a master of technical detail" (Mordaunt Hall quoted in Ringgold and Bodeen 1969:265).

Indeed, DeMille-the-Hollywood-legend was repeatedly honored in numerous genres in a smorgasbord of cinematic references. For example, in the comedy western, Blazing Saddles, a formerly feared and now semi-retired gunfighter, The Waco Kid (Gene Wilder) humorously claimed: "I musta killed more men than Cecil B. DeMille." This intertextual association was frequently noted by critics (e.g., Billingsley 1989:70, Holtzman 1979:263-264) and was itself an allusion to DeMille's successful career as a western filmmaker with obligatory dramatic gunfights (Rivers 1996). In a contemporary film about cinematic illusion, Wag the Dog, film producer Stanley Motss (Dustin Hoffman) talked to the President's Mr. Fix-it, Conrad Brean (Robert De Niro) and mentioned DeMille's production problems concerning elephants in The Greatest Show on Earth, but he was cut off mid-explanation and C.B. was ignored thereafter. This incident was a homage to (and symbolic of) DeMille, "the greatest showman on earth" (Sinyard 1990:145) who did exceptional work that has not been fully analyzed to date. 
The legendary DeMille was also referenced in the relatively recent madcap comedy, Cecil B. DeMented, which was an obvious pun on Cecil B. DeMille's name and famous directorial reputation for "blue-white rage" (Lasky Jr. 1973: 100). This homage was then reinforced via its manic protagonist named Cecil B. DeMented (Stephen Dorff) who led a band of misfit filmmakers to kidnap a famed starlet, Honey Whitlock (Melanie Griffith). The film also contained a second C.B. homage because the title and character of Cecil B. DeMented was originally a newspaper writer's name for its director, John Waters (Ruch 2000:1), that is, an intertextual connection between DeMille and Waters. The film contained a third homage because references to DeMille and the filmmaking business had in effect turned Cecil B. DeMented into "Waters's punk version of "Sunset Boulevard"" (Ruch 2000:2) with its own famous DeMille cameo and the even more famous Norma Desmond (Gloria Swanson) "close-up" comment. A fourth (but reversed) homage occurred when DeMented was portrayed as a low-budget guerilla filmmaker whereas DeMille was a high-budget epic filmmaker.

\section{Imitation as homage: copying DeMille as honoring, flattery and status theft}

On occasion, some directors tried to copy DeMille by attempting to remake scenes from his films as an integral part of their own cinematic creations. For example, James Robertson (1993:7) noted that: "In 1924 [Michael] Curtiz directed his best Austrian feature, The Slave Queen, known as Moon of Israel in Britain and the United States... A virtual remake of Cecil B. de Mille's 1923 The Ten Commandments... The highlight is the Jews' flight across the Red Sea, a sequence involving 5,000 extras and splendid special effects", albeit, nowhere near as successful, honored or as long-lived as DeMille's classic Moses movie, which was "a Hollywood milestone... [and] cannot be denied a place in the Hall of Fame" (Halliwell and Walker 1994:1058). Similarly, R. Dixon Smith (1991:75) noted how the 1926 romantic western, The Winning of Barbara Worth had a catastrophic flood scene which was "carefully constructed in its montage and horrifyingly realistic in its impact, it at least rivaled, if it didn't surpass, the parting of the Red Sea in Cecil B. De Mille's The Ten Commandments" that was screened a few years earlier.

Sometimes, even a hint of a future DeMille production put would-be imitators into a frenzy. As Cecil's niece, Agnes de Mille (1990:192) noted: "When it was known he intended to redo The Ten Commandments [1923], four Egyptian pictures were rushed through ahead of his schedule. He regarded the hubbub with grand amusement. He took his time; he knew his would be the best." Not only was it the best, but it became an iconic film for DeMille, Hollywood and the American biblical epic worldwide (Noerdlinger 1956, Orrison 1999). Even fellow movie mogul Louis B. Mayer wanted to produce "a ten-reeler along the lines of a DeMille biblical epic, Joseph and His Brethren" (Marion 1972:324) as a consequence of Cecil's phenomenal success with the genre. Similarly, Kurt Singer 
(1954:119) reported how Charles Laughton, the star of DeMille's Christian religious drama, The Sign of the Cross: "gave [Alexander] Korda points he had picked up in Hollywood - particularly from Cecil de Mille, the master of spectacle and mob scenes. De Mille, of course, had a Hollywood budget to work with, but certain of his tricks could be duplicated less expensively. The Private Live of Henry VIII employed many of the illusions of De Mille extravaganzas."

Although DeMille was frequently copied to try to garner comparable status, these imitative attempts usually failed dismally. For example, as Paul Swann (1987) reported:

Gabriel Pascal's Caesar and Cleopatra, a notoriously extravagant production which did much to discredit the British film industry through tales in the popular press about transporting sand to Egypt and other excesses... It failed as an attempt to outdo the spectacle which was a staple of many American feature films. It actually did very poorly in the United States, where it was seen by the film trade and by the mass audience as a tired imitation of a Cecil B. De Mille biblical epic (94).

Richard Koszarski (1994:295) noted that when Gloria Swanson and DeMille had parted professional company: "Swanson began a long series of films for Sam Wood that seemed to endlessly repeat the formulas established by DeMille." However, this is not too surprising considering that DeMille made the previously unappreciated Swanson into the queen of Paramount (Franklin 1976:227), while Wood was "Mr. De Mille's favorite assistant director for years" (Swanson 1981:161). Both Swanson and Wood wanted to continue DeMille's successful formula, but they were less successful because they were missing one vital ingredient - Cecil B. DeMille himself.

Scott Eyman (2000:39) argued that Ernst Lubitsch wanted to enter the American market and apparently resorted to imitating DeMille because "the spectacle and psychological realism of Anne Boleyn [1920] derives far more from DeMille's historical melodramas such as Joan the Woman [1917] than from Griffith's spectacles" and that "if Lubitsch was borrowing from anybody in The Marriage Circle [1924] and the films that followed, it was Cecil B. DeMille and the astonishingly nimble series of marital comedies he made beginning in 1918" (Eyman 2000:73). This was another film genre mastered by DeMille-the-filmartist (Higashi 1994, Musser 1995), if also frequently forgotten, even though it fed directly into the screwball comedy that became one of the most notable genres of American cinema (Everson 1994).

Even directors directly remaking DeMille's films using DeMille personnel could not automatically ensure their product would achieve Cecil's level of success. For example, his 1915 American Civil War story, The Warrens of Virginia was remade in 1924 by director Elmer Clifton, but it had "little to recommend it" (Holsinger 1999:142), even though its scriptwriter was William C. de Mille, Cecil's brother. In a comical vein, DeMille's Charlton Heston (Moses) in the 1956 The Ten Commandments was imitated in the 1981 farcical film, History of the World - Part I when its Moses (Mel Brooks) descended, Charlton Heston- 
like, from the holy mountain top after having spoken to God. He was carrying three stone tablets containing God's fifteen commandments, but he stumbled and dropped a tablet, which shattered upon the ground. Nevertheless, he stoically continued down the mountain to reveal God's word to the world with the now famous ten commandments of Judeo-Christianity.

Given DeMille's directorial longevity and aesthetic successes, he influenced the style and scenes of many film greats who imitated Cecil simply because it was great cinema. For example, as film historian James Card (1994) pointed out:

In his first Ten Commandments [1923], DeMille had Nita Naldi die a spectacular death behind a curtain. Instead of watching the sinister Sally Lung die, we saw the curtain being torn from its mooring, rung by rung, as she expired behind it. Rene Clement has Dalio [Larga] die the same way in the French film The Damned [1947]-a great melodrama of Nazis fleeing retribution aboard a submarine. Alfred Hitchcock himself was not above swiping a scene from DeMille. He did it in Psycho [1960] (226).

Hitchcock's assistant director, Hilton Green, noted that the shower scene in Psycho "became the most famous sequence in the picture" (Rebello 1990:106), but few commentators have acknowledged DeMille's powerful influence upon Hitchcock's art here (e.g., Birchard 2004:189). Similarly, King Vidor borrowed DeMille's point-of-view shot of the construction elevator racing towards the heavens for his The Fountainhead (Birchard 2004:189), while Francois Truffaut noted Mikhail Romm's enormous stylistic debt to DeMille for Admiral Ushakov (Dixon 1993:129). James Card (1979) reported how Georg Wilhelm Pabst had copied an unorthodox death scene played by Theodore Roberts from DeMille's 1918 society drama, Old Wives for New. Namely:

He is shot by his mistress. He does not pitch over onto the floor. Instead, DeMille has him, in shock, walk somewhat uncertainly, over to the bed. He sits on it, very carefully. Flecks of blood begin to appear from within his starched dress shirt. He takes minutes to die with disbelief replaced by vast annoyance. It is a scene that almost shot for shot is duplicated by Pabst when he has Dr. Schoen [Fritz Kortner] shot by Lulu [Louise Brooks] in his 1928 The Box of Pandora (118-119).

The 1955 Ancient Egyptian drama, Land of the Pharaohs had a frightening alligator scene that may have been inspired by DeMille's 1921 Fool's Paradise. After all, Sumiko Higashi (1996b:345) noted the scene wherein Arthur Phelps (Conrad Nagel) fights "off hungry reptiles with a wooden stick and a dinner jacket. A spectacle often repeated today in such box-office winners as Indiana Jones and the Temple of Doom" and which was refreshingly reincarnated in Live and Let Die when James Bond (Roger Moore) got out of trouble by running across the floating backs of menacing crocodiles.

A cinematic homage to DeMille was strikingly self-evident in DeMille's 1952 Oscar-winning circus epic, The Greatest Show on Earth. It starred James Stewart as Buttons the clown who was being pursued by the police for the murder/merciful euthanasia of his wife, and so he hid inside the circus world and did not remove 
his clown makeup. Despite its serious social subtext (and another feature of DeMille's films frequently overlooked), it was comically parodied in Europe:

It was Italy that had the most satiric reaction, however, when the noted comic Toto starred in The Funniest Show on Earth [1953]. In a parody of the Stewart character, he [Tottons, the clown] played a murderer of chickens who gets tracked down by a detective who trails after a circus across Italy measuring footprints in order to match them with those found in a coop (Dewey 1996:328).

An attempt was also made in America to achieve the success of The Greatest Show on Earth by imitating it. As Kevin Mace (1986:30) reported: "The Big Circus (1959) is about a circus beset with many problems, including sabotage by a rival company. It was dismissed by many viewers as a poor imitation of The Greatest Show on Earth (1952)." Not only was the circus genre and its disaster theme copied, but its cast members also included notable DeMille actors, namely, Victor Mature as the circus boss Hank Whirling (Samson in Samson and Delilah), Vincent Price as the performer Hans Hagenfeld (Baka in the 1956 The Ten Commandments), and the film's scriptwriter, Charles Bennett who had previously worked on DeMille's Reap the Wild Wind, The Story of Dr. Wassell and Unconquered. Since The Big Circus was a commercial and artistic flop, it lends considerable credence to DeMille's claim that: "No one can make a DeMille movie without DeMille!" (Wilcoxon and Orrison 1991:327). Dore Schary (1979) came to the same essential conclusion regarding his DeMille copying attempt. As he ruefully claimed:

The biggest and most embarrassing failure was The Prodigal [1955]. Charlie Schnee wrote and produced it and Richard Thorpe directed. In all candor, I hustled Lana Turner [Samarra] into playing opposite Edmund Purdom [Micah], who had not yet made his move for the big money he claimed to deserve. The sorry fact is I liked the script. I thought it would draw an audience. What I forgot was that C. B. DeMille had an exclusive on the Bible. Poor Lana swayed her way through the film, but it was a hopeless task. The script was lifeless (283).

Australian film director Bruce Beresford came to a similarly dismaying conclusion concerning his own OT film, King David starring Richard Gere as David. He wanted to get away from DeMille's biblical style and attempted to do for the OT what Pier Paolo Pasolini had done for the NT with The Gospel According to St. Matthew, but he failed miserably. Instead of fame and glory, Beresford produced a flat film containing no DeMillean style, mystery or religious awe. As he candidly admitted later about his anti-DeMille stance: "I must have been a half-wit" (Coleman 1992:100).

Kinnard and Davis (1992:74) argued that "the 1951 Quo Vadis also owes a great deal to Cecil B. DeMille's 1932 The Sign of the Cross, particularly in Ustinov's effete interpretation of the Emperor Nero, originally played by Charles Laughton in the DeMille film." Not only was Laughton gay in real life, but DeMille allowed him to turn his Nero into an outrageous queen, complete with a young, male catamite at his side (Callow 1987:51). The imitative DeMille touch 
was also very evident in the contemporary comedy, Coming to America starring Eddie Murphy as Prince Akeem, especially with its "fairy-tale view of a mythical African kingdom [which] hardly seems to spring from a black sensibility. It is oldstyle Hollywood fakery. During an early lavish ceremonial sequence, the troupe of black dancers cavorting across the screen is reminiscent of the Ethiopian contingency in Cecil B. DeMille's 1956 The Ten Commandments" (Bogle 1995: 286). The resultant spectacle did both movies proud, and was not bad for a DeMillean stylistic that had been successfully echoed over three decades later.

Aesthetically speaking, in another genre and world away, Aaron Sultanik (1986:142) noted that Hiroshi Inagaki's "Samurai trilogy reveals its DeMille-like signature in [Toshiro] Mifune's tense, overwrought child-hero whose rise to a master swordsman is presented in hackneyed psychological episodes," and that "Two of [David] Lean's less successful adventure epics, The Bridge on the River Kwai and Doctor Zhivago, like several De Mille projects, attempts to elevate their two-dimensional characters into transcendental figures of heroism and romance." Nevertheless, these five films were magnificent "failures" that sit very well alongside DeMille's successful spectacular epics.

In a similar imitative vein, Marcia Landy $(1986: 195,197)$ noted an affinity between the films of DeMille and the 1937 Italian film, Scipione l'Africano, particularly the character of Queen Sofonisba (Francesca Braggiotti) whose "make-up, her clinging garments, her sensual movements, her passion, identify her as a descendant of the 1920 s film... a relative too of the femme fatale in a De Mille epic." Similarly, Friar and Friar (1972) argued that:

Corinna Tsopei [Running Deer] in A Man Called Horse (Elliot Silverstein), prior to her marriage to the white man, goes through a sweat lodge purification ritual (there was no such ritual before marriage among the Sioux). The audience sees her naked from the waist up. It doesn't take long to realize that this scene is only a variation of De Mille's famous heroine bathing scenes-only De Mille did it better (240).

Interestingly, Martin Rubin (1993) noted how Busby Berkeley and DeMille had emulated each other many times in their respective film careers. As he claimed:

DeMille himself directed a semi-Berkeleyesque musical, Madame Satan (1930). The scene of Anthony's seduction on a magnificent barge in DeMille's nonmusical Cleopatra (1934) - with voluptuous water nymphs bearing jewel-filled clam shells, giant platters groaning with steaming delicacies, leopard-skinned slave girls driven by a whip-wielding keeper and tumbling through flaming hoops, etc. - is virtually a full-scale Berkeley production number. For his part, Berkeley crossed paths with the "DeMillesque" in such mixtures of the monumental, the exotic, and the erotic as "No More Love" (Roman Scandals, 1933) and "Totem Tom Tom" (Rose Marie, 1954). This relationship between DeMillesque spectacle and Berkeleyesque spectacle was noted by critics even before Berkeley came to Hollywood... a New York Times news item on the Philadelphia tryout of the International Revue (1930; special dance arrangements by Berkeley) reported, "The Philadelphia Public Ledger was moved to 
say tersely, 'More DeMillish than DeMille' - an erudite synonym for splendour (41-42).

This comment also confirmed that DeMille was capable of committing acts of homage himself as well as being the subject or object of it.

\section{Association as homage: capitalizing upon DeMille's currency, name and reputation}

On other occasions, some filmmakers tried vigorously to capitalize upon DeMille's currency, name and reputation. For example, Charlie Chaplin was so impressed with DeMille's 1915 gypsy film, Carmen (the then rage of Hollywood) that he quickly parodied it in his 1916 film Charlie Chaplin's Burlesque on Carmen hoping to piggy-back upon DeMille's success. Similarly, Raoul Walsh's 1925 The Wanderer was an adaptation of the Old Testament story about the Prodigal Son (Luke 15:11-32 KJV), and was intended as a biblical follow-up to Cecil's 1923 The Ten Commandments (Brownlow 1990:26), but it never achieved the same level of success as Cecil's superior effort. Similarly, the 1927 war comedy, With Love and Hisses blatantly associated the comedic team of Stan Laurel and Oliver Hardy with DeMille's name, fame and film when:

Stan plays a meek army recruit [Cuthbert Hope] who is assigned by Sergeant Ollie [Top Sergeant Banner] to guard a pile of soldiers' uniforms as the troops swim in a nearby lake. Moments after Ollie tosses his lit cigarette into the clothing, Stan decides to join the rest of the group. Following the destruction of their uniforms, Ollie and his troops must hide themselves behind a billboard advertising the Cecil B. DeMille film The Volga Boatman [1926]. As the men replace the painted heads of the Russians with their own, a skunk forces them to leave, carrying the huge billboard with them (Nollen 1989:62).

Alternatively, it may have been a cunning marketing exercise by DeMille-thebusinessman.

Even movie moguls compared themselves to DeMille and his reputation for toughness and tenacity. For example, Louis B. Mayer once claimed: "I intend to show Schenck and his gang that a man of power never loses his potency. I'll be like DeMille and fight them singlehanded" (Marion 1972:325). Director Howard Hawks even went as far as to capitalize upon the advertising iconography of DeMille's 1949 Samson and Delilah and use it in his poster for his 1955 Land of the Pharaohs. The poster was so imitative that Edwards and Cross (1984:22) wryly commented in Worst Movie Posters of All Time: A Treasury of Trash: "Is this Land of the Pharaohs or Samson and Delilah? Does it matter? Both feature muscle-men, the inevitable toppling idols and sultry temptresses in funny bras." Yet, what it did prove, once again, was that what worked for DeMille did not necessarily work for other directors, including Hawks, no matter how close the DeMillean surface parallels were. 
Nevertheless, there were positive marketing advantages for filmmakers to associate themselves and their products with DeMille. For example, when Warner Bros. announced that they were filming the Shakespearean drama, A Midsummer Night's Dream, it was claimed that it "would rival a DeMille spectacular" (Marion 1972:253) even though Cecil was not a Shakespeare scholar, theatre director or English dramatist. By evoking the name of Paramount's DeMille, it had associated their product with the good times and box-office successes associated with Cecil's cinema, which Warner Bros. hoped would translate into box-office profits for themselves, and without the need to pay DeMille anything for his free, indirect and unauthorized endorsement.

\section{Remodeling as homage: the spin-offs, remakes and rivals of DeMille's films}

According to John Baxter (1976:14), King Vidor's 1922 Conquering the Woman was "an obvious spin-off” from DeMille's 1919 Male and Female. Ringgold and Bodeen (1969:10) suggested that Sam Wood's 1921 Don't Tell Everything grew from a sequence excised from DeMille's 1921 The Affairs of Anatol. DeMille's 1918 The Whispering Chorus was subsequently remade in 1927 as The Way of All Flesh starring Emil Jannings, and then remade again in 1940 as The Way of All Flesh starring Akim Tamiroff (Bodeen 1982:1223). DeMille's 1922 Manslaughter starring Thomas Meighan and Leatrice Joy was remade in 1930 as Manslaughter starring Fredric March and Claudette Colbert, and then remade again in 1936 as And Sudden Death starring Randolph Scott and Frances Drake (Bowers 1982:705). DeMille even remade his own western, The Squaw Man, not once but three times (1914, 1918 and then again 1931 during his brief MGM years following his dispute with Paramount).

Although DeMille did make two Moses movies called The Ten Commandments in 1923 and 1956 respectively, the sound version was not technically a remake of the silent film, which had a two-part structure, namely, an Ancient Egypt story followed by a then modern-day American story, whereas the sound version was exclusively devoted to Ancient Egypt, the Exodus and the tribulation of the Hebrews (Higashi 1996a). Similarly, DeMille's 1937 western, The Plainsman was remade for TV in 1966, also called The Plainsman, "but it was a pale imitation of the original with Don Murray as Hickok and Abby Dalton as Calamity Jane" (Pitts 1984:233). As Brian Dippie (1994:105) reported concerning it: "Though the critics had few kind words for it, the remake was an impressive tribute to the indestructible reputation of the 1937 original," which itself has been grossly misunderstood and underrated (Kozlovic 2003). Interestingly, Jon Tuska (1985:179) suggested that Paramount's 1953 Pony Express starring Charlton Heston "might well be regarded as an unofficial remake of The Plainsman."

Nor were DeMille's rivals necessarily superficial. Some directors vigorously tried to out-DeMille DeMille in such ancient world productions as the 1959 Solomon and Sheba, which itself used DeMille's biblical stars, namely, George 
Sanders as Adonijah (The Saran of Gaza from Samson and Delilah) and Yul Brynner as Solomon (Pharaoh Rameses from the 1956 The Ten Commandments). Similarly, the 1959 Ben-Hur starred Charlton Heston as Judah Ben-Hur (Brad in The Greatest Show on Earth and Moses in the 1956 The Ten Commandments), and Martha Scott as Miriam (Yochabel in 1956 The Ten Commandments). The OT Solomon and Sheba was a dramatic failure as a biblical picture and as a DeMille imitation (Kozlovic 2002), whereas the NT-flavored Ben-Hur became a stunning epic success that many people today still think DeMille had directed rather than William Wyler, in addition to the public confusing the catch-phrase "Bigger than Ben-Hur" with DeMille (i.e., another variation of misidentification-as-homage).

\section{Conclusion}

These five heuristic categories of homage are just the beginning of research into film studies terminology and the identification of their various categories and sub-categories. As for the man, Hollywood owes much to DeMille and his farreaching influence upon American cinema, history and culture, whether to imitate, challenge or surpass this self-confessed pop culture professional (DeMille and Hayne 1960:195). He is certainly as indelible as Hollywood itself, and can no longer be denied his rightful place as a ground-breaking director, although many have tried to dismiss him: "Indeed, with the exception of D. W. Griffith and Eric von Stroheim, no other director has been exposed to such vicious abuse and character assassination" (Feldman and Feldman 1950:1). Nevertheless, if the following old adage is true, namely: "imitation is the sincerest form of flattery" then Cecil B. DeMille must be very flattered indeed.

Although there were many imitations, there was only one DeMille who was truly "sui generis" (Louvish 2008:429). When he died in 1959, it spelled the end of an incredible career that had survived the genesis of Hollywood, the birth of feature length films, sound films, color films, numerous technological advances, World War I and II, the Korean War, the Wall Street crash, shifting consumer demographics, changing public tastes, fluctuating finances, fickle fads and the ever-growing threat of the small screen - television. Moreover, the golden age of Hollywood died with him and so we will never see his likes again. No wonder DeMille was called "Mr. Motion Picture" (Essoe and Lee 1970:208), "Mr. Hollywood" (Higashi 1985:1), and "Mr. Movies" (Capra 1997:439) amongst many other honorary industry hosannas. He was that important, and yet ironically, he is still Hollywood's best-known, unknown. As Simon Louvish (2008:xv) noted: "The curious, and somewhat stunning, fact of the life in art of Cecil B. DeMille is that most of his best, most intriguing, most masterfully crafted and indeed amazing movies remain invisible and unknown, even to film buffs who were brought up on the legendary sagas of this iconic movie-maker." Therefore, further researches into unveiling DeMille studies, interdisciplinary homage typologies and their Hollywood histories are warranted, recommended and are already long overdue. 
Address:
Anton Karl Kozlovic
11 Caroline Drive
Fulham Gardens
South Australia 5024
Australia

Tel.: +618 83569268

E-mail: antonkozlovic@hotmail.com, Anton.Kozlovic@ flinders.edu.au

\section{References}

Allen, Graham (2000) Intertextuality. London: Routledge.

Anger, Kenneth (2006) In conversation: Kenneth Anger with Pip Chodorov. <http://brooklynrail.org/ 2006/05/film/kenneth-anger-with-pip-chodorov>, 1-8 (accessed December 20, 2008).

Armes, Roy (1975) Film and reality: an historical survey. Harmondsworth: Penguin.

Babington, Bruce and Peter W. Evans (1993) Biblical epics: sacred narrative in the Hollywood cinema. Manchester: Manchester University Press.

Baxter, John (1976) King Vidor. New York, NY: Monarch Press.

Baxter, John (1996) Steven Spielberg: the unauthorised biography. London: Harper-Collins Publishers.

Billingsley, K. Lloyd (1989) The seductive image: a Christian critique of the world of film. Westchester, IL: Crossway Books.

Birchard, Robert S. (2004) Cecil B. DeMille's Hollywood. Lexington: University Press of Kentucky.

Bodeen, DeWitt (1982) "The Whispering Chorus". In Magill's survey of cinema. Silent films. Volume 3, 1221-1223. Frank N. Magill, ed. Englewood Cliffs, NJ: Salem Press.

Bogle, Donald (1995) Toms, coons, mulattoes, mammies, and bucks: an interpretative history of Blacks in American films, $3^{\text {rd }}$ ed. New York: Continuum.

Bowers, Ronald (1982) "Manslaughter". In Magill's survey of cinema. Silent films. Volume 2, 702705). Frank N. Magill, ed. Englewood Cliffs, NJ: Salem Press.

Brode, Douglas (1995) The films of Steven Spielberg. New York, NY: Citadel Press.

Brownlow, Kevin (1990) Behind the mask of innocence. New York: Alfred A. Knopf.

Bywater, Tim and Thomas Sobchack (1989) An introduction to film criticism: major critical approaches to narrative film. New York: Longman.

Callow, Simon (1987) Charles Laughton: a difficult actor. London: Methuen.

Capra, Frank (1997) The name above the title: an autobiography. New York: Da Capo Press.

Card, James (1994) Seductive cinema: the art of silent film. New York: Alfred A. Knopf.

Cherchi Usai, Paolo and Lorenzo Codelli, eds. (1991) The DeMille legacy. Pordenone: Le Giornate del Cinema Muto/Edizioni Biblioteca dell'Immagine.

Clapham, Walter C. (1974) The movie treasury. Western movies: the story of the West on screen. London: Octopus Books.

Coleman, Peter (1992) Bruce Beresford: instincts of the heart. Pymble, NSW: Angus \& Robertson.

Crawley, Tony (1983) The Steven Spielberg story. London: Zomba Books.

de Mille, Agnes (1990) Portrait gallery. Boston: Houghton Mifflin.

DeMille, Cecil B. and Donald Hayne, ed. (1960) The autobiography of Cecil B. DeMille. London: W. H. Allen.

Dewey, Donald (1996) James Stewart: a biography. Atlanta: Turner Publishing.

Dippie, Brian W. (1994) Custer's last stand: the anatomy of an American myth. Lincoln: University of Nebraska Press.

Dixon, Wheeler Winston (1993) The early film criticism of Francois Truffaut. Bloomington: Indiana University Press.

Edwards, Anne (1988) The DeMilles: an American family. London: Collins.

Edwards, Gregory J. and Robin Cross (1984) Worst movie posters of all time: a treasury of trash. London: Sphere Books. 
Elley, Derek, ed. (1994) Variety movie guide. London: Hamlyn.

Essoe, Gabe and Raymond Lee (1970) DeMille: the man and his pictures. New York: Castle Books.

Everson, William K. (1994) Hollywood bedlam: classic screwball comedies. Secaucus, NJ: Carol Publishing Group.

Eyman, Scott (2000) Ernst Lubitsch: laughter in paradise. Baltimore, MD: The John Hopkins University Press.

Feldman, Joseph and Harry Feldman (1950) "Cecil B. DeMille's virtues". Films in Review 1, 9, 1-6.

Finler, Joel W. (1985) The movie directors story. London: Octopus Books.

Franklin, Joe (1976) Classics of the silent screen: a pictorial treasury. Secaucus, NJ: The Citadel Press.

Friar, Ralph E. and Natasha A. Friar (1972) The only good Indian... The Hollywood gospel. New York: Drama Book Specialists.

Halliwell, Leslie and John Walker, ed. (1994) Halliwell's film guide, $10^{\text {th }}$ ed. London: HarperCollinsPublisher.

Hammond, Joyce (1996) "Drag queen as angel: transformation and transcendence in To Wong Foo, Thanks for Everything, Julie Newmar". Journal of Popular Film and Television 24, 3, 106114.

Higashi, Sumiko (1985) Cecil B. DeMille: a guide to references and resources. Boston, MA: G. K. Hall \& Co.

Higashi, Sumiko (1994) Cecil B. DeMille and American culture: the silent era. Berkeley: University of California Press.

Higashi, Sumiko (1996a) "Antimodernism as historical representation in a consumer culture: Cecil B. DeMille's The Ten Commandments, 1923, 1956, 1993”. In The persistence of history: cinema, television, and the modern event, 91-112. Vivian Sobchack, ed. New York: Routledge.

Higashi, Sumiko (1996b) "Touring the Orient with Lafcadio Hearn and Cecil B. DeMille: highbrow vs lowbrow in a consumer culture". In The birth of whiteness: race and the emergence of U.S. cinema, 329-353. Daniel Bernardi, ed. New Brunswick, NJ: Rutgers University Press.

Higham, Charles (1973) Cecil B. DeMille. New York: Charles Scribner's Sons.

Holloway, Ronald (1977) Beyond the image: approaches to the religious dimension in the cinema. Geneva: World Council of Churches.

Holsinger, M. Paul (1999) War and American popular culture: a historical encyclopedia. Westport, CT: Greenwood Press.

Holtzman, William (1979) Seesaw: a dual biography of Anne Bancroft and Mel Brooks. Garden City, NY: Doubleday.

Hopkins, Charles (1980) "Cleopatra". In Magill's survey of cinema. English language films. First series. Volume 1, 356-361. Frank N. Magill, ed. Englewood Cliffs, NJ: Salem Press.

Kardish, Laurence (1972) Reel plastic magic: a history of films and filmmaking in America. Boston: Little, Brown.

Kinnard, Roy and Tim Davis (1992) Divine images: a history of Jesus on the screen. New York, NY: Citadel Press.

Konigsberg, Ira (1989) The complete film dictionary. New York, NY: Meridian.

Koszarski, Richard (1994) History of the American cinema. 3. An evening's entertainment: the age of the silent feature picture 1915-1928. Berkeley: University of California Press.

Koury, Phil A. (1959) Yes, Mr. De Mille. New York: Putnam.

Kozlovic, Anton Karl (2002) "DeMille \& Vidor: failed imitation as flattery". 24 Frames Per Second, 2, 1-5. [http://www.24framespersecond.com/writings/writings/demille.html] (link inactive January 12, 2006).

Kozlovic, Anton Karl (2003) “The Plainsman (1937): Cecil B. DeMille's greatest authenticity lapse?" Kinema: A Journal for Film and Audiovisual Media 19, 73-86.

Kreitzer, Larry J. (2003) "Film". In Jesus in history, thought, and culture: an encyclopedia. Volume 1, 288-292. Leslie Houlden, ed. Santa Barbara, CA: ABC-CLIO.

Landy, Marcia (1986) Fascism in film: the Italian commercial cinema, 1931-1943. Princeton, NJ: Princeton University Press. 
Lasky Jr., Jesse L. (1973) Whatever happened to Hollywood? London: W. H. Allen.

Lasky, Jesse L. and Don Weldon (1957) I blow my own horn. London: Victor Gollancz.

Louvish, Smon (2008) Cecil B. DeMille: a life in art. New York: Thomas Dunne Books/St. Martin's Press.

Mace, Kevin (1986) "Charles Bennett (1899- )". In American screenwriters. Second series, 23-31. Randall Clark, ed. Detroit, MI: Gale Research.

Marion, Frances (1972) Off with their heads!: a serio-comic tale of Hollywood. New York: Macmillan.

McConnell, Frank (1979) Storytelling and mythmaking: images from film and literature. New York: Oxford University Press.

Musser, Charles (1995) "Divorce, DeMille and the comedy of remarriage". In Classical Hollywood comedy, 282-313, 392-398. Kristine B. Karnick and Henry Jenkin, eds. New York: Routledge.

Noble, Peter (1950) Hollywood scapegoat: the biography of Erich von Stroheim. London: The Fortune Press.

Noerdlinger, Henry S. (1956) Moses and Egypt: the documentation to the motion picture The Ten Commandments. Los Angeles: University of Southern California Press.

Nollen, Scott A. (1989) The boys: the cinematic world of Laurel and Hardy. Jefferson, NC: McFarland.

Norman, Barry (1985) The film greats. London: Hodder and Stoughton/British Broadcasting Corporation.

Orrison, Katherine (1999) Written in stone: making Cecil B. DeMille's epic, The Ten Commandments. Lanham: Vestal Press.

Paglia, Camille (1994) Vamps \& tramps: new essays. New York: Vintage Books.

Perry, George (1993) Sunset Boulevard: from movie to musical. London: Pavilon.

Pfeiffer, Lee (2006) The complete idiot's guide to classic movies. New York, NY: Alpha.

Pitts, Michael R., comp. (1984) Hollywood and American history: a filmography of over 250 motion pictures depicting U.S. history. Jefferson, NC: McFarland.

Rebello, Stephen (1990) Alfred Hitchcock and the making of Psycho. New York, NY: HarperPerennial.

Ringgold, Gene and DeWitt Bodeen (1969) The complete films of Cecil B. DeMille. Secaucus, NJ: The Citadel Press.

Rivers, Jennifer A. (1996) Cecil B. DeMille's vision of the West: a comparison of history and film. MA dissertation, Brigham Young University.

Robertson, James C. (1993) The Casablanca man: the cinema of Michael Curtiz. London: Routledge.

Rubin, Martin (1993) Showstoppers: Busby Berkeley and the tradition of spectacle. New York: Columbia University Press.

Ruch, John (2000) 90 minutes closer to being dead: movie reviews from America's Gilded Age, 1994-2001: Cecil B. Demented (2000). <http://90minutesarchives.stupidquestion.net/ cecilbdemented.html>, 1-2 (accessed December 20, 2008).

Schary, Dore (1979) Heyday: an autobiography. Boston: Little, Brown.

Singer, Kurt (1954) The Laughton story: an intimate story of Charles Laughton. Philadelphia: The John C. Winston Company.

Sinyard, Neil (1986) The films of Steven Spielberg. London: Bison Books.

Sinyard, Neil (1990) Silent movies. London: Bison Books.

Smith, R. Dixon (1991) Ronald Colman, gentleman of the cinema: a biography and filmography. Jefferson, NC: McFarland.

Sultanik, Aaron (1986) Film: a modern art. New York: Cornwall Books.

Swann, Paul (1987) The Hollywood feature film in postwar Britain. New York: St. Martin's Press.

Swanson, Gloria (1981) Swanson on Swanson. London: Michael Joseph.

Tuska, Jon (1985) The American West in film: critical approaches to the western. Westport, CT: Greenwood Press.

Vidal, Gore (1995) Palimpsest: a memoir. London: Andre Deutsch. 
Wilcoxon, Henry and Katherine Orrison (1991) Lionheart in Hollywood: the autobiography of Henry Wilcoxon. Metuchen, NJ: The Scarecrow Press.

\section{Filmography}

Admiral Ushakov (1953, dir. Mikhail Romm)

The Affairs of Anatol (1921, dir. Cecil B. DeMille)

A Man Called Horse (1970, dir. Elliot Silverstein)

A Midsummer Night's Dream (1935, dir. William Dieterle \& Max Reinhardt)

And Sudden Death (1936, dir. Charles Barton)

Anne Boleyn (a.k.a. Anna Boleyn) (1920, dir. Ernst Lubitsch)

Ben-Hur: A Tale of the Christ (a.k.a. Ben-Hur) (1925, dir. Fred Niblo)

Ben-Hur (a.k.a. Ben-Hur: A Tale of the Christ) (1959, dir. William Wyler)

The Big Circus (1959, dir. Joseph M. Newman)

Blazing Saddles (1974, dir. Mel Brooks)

The Bridge on the River Kwai (1957, dir. David Lean)

The Box of Pandora (a.k.a. Die Buchse der Pandora) (1928, dir. Georg Wilhelm Pabst)

Caesar and Cleopatra (1945, dir. Gabriel Pascal)

Carmen (1915, dir. Cecil B. DeMille)

Cecil B. DeMented (a.k.a. Cecil B. Demented) (2000, dir. John Waters)

Charlie Chaplin's Burlesque on Carmen (1916, dir. Charlie Chaplin)

Cleopatra (1934, dir. Cecil B. DeMille)

Close Encounters of the Third Kind (1977, dir. Steven Spielberg)

Coming to America (1988, dir. John Landis)

Conquering the Woman (1922, dir. King Vidor)

The Crusades (1935, dir. Cecil B. DeMille)

The Damned (a.k.a. Les Maudits) (1947, dir. Rene Clement)

Doctor Zhivago (1965, dir. David Lean)

Don't Tell Everything (1921, dir. Sam Wood)

Dynamite (1929, dir. Cecil B. DeMille)

Fool's Paradise (1921, dir. Cecil B. DeMille)

The Fountainhead (1949, dir. King Vidor)

The Funniest Show on Earth (a.k.a. Il Piu Comico Spettacolo del Mondo) (1953, dir. Mario Mattoli)

The Gospel According to St. Matthew (1964, dir. Pier Paolo Pasolini)

The Greatest Show on Earth (1952, dir. Cecil B. DeMille)

History of the World - Part I (1981, dir. Mel Brooks)

Indiana Jones and the Temple of Doom (1984, dir. Steven Spielberg)

Joan the Woman (1917, dir. Cecil B. DeMille)

Joseph and His Brethren (1962, dir. Irving Rapper)

Kanya Ya Ma Kan, Beyrouth (a.k.a. Once Upon a Time in Beirut) (1995, dir. Jocelyn Saab)

King David (1985, dir. Bruce Beresford)

The King of Kings (1927, dir. Cecil B. DeMille)

Land of the Pharaohs (1955, dir. Howard Hawks)

The Last Journey to Jerusalem (unknown date or director)

Live and Let Die (1973, dir. Guy Hamilton)

Madame Satan (1930, dir. Cecil B. DeMille)

Male and Female (1919, dir. Cecil B. DeMille)

Manslaughter (1922, dir. Cecil B. DeMille)

Manslaughter (1930, dir. George Abbott)

The Marriage Circle (1924, dir. Lubitsch)

Modern Commandments (1927, dir. Dorothy Arzner)

The Naked Gun 2 1/2: The Smell of Fear (1991, dir. David Zucker)

Old Wives for New (1918, dir. Cecil B. DeMille) 
The Plainsman (1937, dir. Cecil B. DeMille)

The Plainsman (1966, dir. David Lowell Rich)

Pony Express (1953, dir. Jerry Hopper)

The Private Live of Henry VIII (1933, dir. Alexander Korda)

The Prodigal (1955, dir. Richard Thorpe)

Psycho (1960, dir. Alfred Hitchcock)

Quo Vadis (1951, dir. Mervyn LeRoy)

Reap the Wild Wind (1942, dir. Cecil B. DeMille)

Roman Scandals (1933, dir. Frank Tuttle)

Rose Marie (1954, dir. Mervyn LeRoy)

Samson and Delilah (1949, dir. Cecil B. DeMille)

Samurai I: Musashi Miyamoto (1954, dir. Hiroshi Inagaki)

Samurai II: Duel at Ichijoji Temple (1955, dir. Hiroshi Inagaki)

Samurai III: Duel at Ganryu Island (1956, dir. Hiroshi Inagaki)

Scipione l'Africano (a.k.a. Scipio Africanus: The Defeat of Hannibal) (1937, dir. Carmine Gallone)

Scorpio Rising (1964, dir. Kenneth Anger)

The Sign of the Cross (1932, dir. Cecil B. DeMille)

The Slave Queen (a.k.a. Moon of Israel) (1924, dir. Michael Curtiz)

Solomon and Sheba (1959, dir. King Vidor)

Special Effects: Anything Can Happen (1996, dir. Ben Burtt)

The Squaw Man (1914, dir. Cecil B. DeMille)

The Squaw Man (1918, dir. Cecil B. DeMille)

The Squaw Man (1931, dir. Cecil B. DeMille)

The Story of Dr. Wassell (1944, dir. Cecil B. DeMille)

Sunset Blvd. (1950, dir. Billy Wilder)

The Ten Commandments (1923, dir. Cecil B. DeMille)

The Ten Commandments (1956, dir. Cecil B. DeMille)

To Wong Foo, Thanks for Everything! Julie Newmar (1995, dir. Beeban Kidron)

Unconquered (1947, dir. Cecil B. DeMille)

The Volga Boatman (1926, dir. Cecil B. DeMille

Wag the Dog (1997, dir. Barry Levinson)

The Wanderer (1925, dir. Raoul Walsh)

The Warrens of Virginia (1915, dir. Cecil B. DeMille)

The Way of All Flesh (1927, dir. Victor Fleming)

The Way of All Flesh (1940, dir. Louis King)

The Whispering Chorus (1918, dir. Cecil B. DeMille)

Widows' Peak (1994, dir. John Irvin)

The Winning of Barbara Worth (1926, dir. Henry King)

With Love and Hisses (1927, dir. Fred Guiol) 